DOI: 10.17707/AgricultForest.63.2.12

\author{
Sladjana VIĆENTIĆ, Branko KANJEVAC, Jovana PETROVIĆ, \\ Milun KRSTIĆ, Violeta BABIĆ and Nenad STAVRETOVIĆ ${ }^{1}$
}

\title{
ANALYSIS OF DENDROFLORA ON THE GREEN AREAS OF SOME KINDERGARTENS IN BELGRADE (SERBIA)
}

\begin{abstract}
SUMMARY
Green areas of kindergartens and schools represent an important part of the system of a city's greenery and perform a range of functions like ecological, environmental, sanitary, aesthetic, educational, recreational, etc. These areas may have some woody species which are of an invasive or allergenic character. Allergenic woody species may negatively influence the children's health, or provoke certain allergic reactions. Since children spend most of their time in kindergartens, the research of the presence of allergenic species in these areas is very important. Invasive woody species could threaten biodiversity and disturb aesthetics of the green kindergarten's area by sudden and quick spreading. The research has been carried out on the green areas of four kindergartens in Belgrade. This research consists of the survey of the main elements of tree growth, the assessment of vitality and decorativeness of each tree as well as the establishment of the number of allergens and invasive species on every researched area. The obtained data have been processed in the statistical program SPSS Statistics 17.0. The results have shown the presence of 41 plant species with the total number of 359 trees on those 4 researched areas. One invasive species (Robinia pseudoacacaia L.) with the total number of 38 trees $(10.6 \%)$ is present. 12 allergenic species with 133 trees have been ascertained, which is $37.0 \%$ of the total number. The species Betula pendula Roth., which pollen has very conspicuous allergenic characteristics, is present with 17 trees, and the species of the genus Tilia spp., with moderately to strongly conspicuous characteristics of pollen, with 21 tree.
\end{abstract}

Keywords: allergenic plants, dendroflora, invasive species, green areas of kindergartens

\section{INTRODUCTION}

Urban forests and green areas can improve environmental conditions and quality of life in cities (Pretzsch et al. 2015). In urban environment, urban forests and green areas interconnect ecosystems and are an indicator of sustainability (Jankovska et al. 2014). Planning of green spaces gives as a result better quality

\footnotetext{
${ }^{1}$ Sladjana Vićentić, corresponding author: sladjanavicentic@yahoo.com), Branko Kanjevac, Jovana Petrović, Milun Krstić, Violeta Babić and Nenad Stavretović, University of Belgrade, Faculty of Forestry, Kneza Višeslava 1, Belgrade, Serbia.

Notes: The authors declare that they have no conflicts of interest. Authorship Form signed online.
} 
of life in the cities and higher value of space in general (Vukotić-Lazar et al. 2016)

The greenery of kindergartens and schools is an important part of the system of a city's greenery. Besides that, the green areas of these objects have a great significance regarding sports and recreation of children. The green areas of kindergartens, schools and other educational institutions have multiple functions like ecological, sanitary, educational and recreational (Gačić and Stavretović 2008). Numerous authors (Fjørtoft 2004, White 2004, Bell and Dyment 2008, Dyment et al. 2009, Lucas et al. 2010) indicate the positive influence of green areas on social, psychological and motor development of children.

The composition and characteristic of the existing woody species on the green areas of kindergartens affect their aesthetics and functionality. Besides this, these areas may have some woody species which are of an invasive or allergenic character. Allergenic woody species may negatively influence the children's health, or provoke certain allergic reactions. Pollen allergies are seasonal diseases that are related to the time of flowering allergenic plants (Nestorović et al. 2011). Pollen various grasses, trees and weeds cause in sensitive people allergic reactions. The most common allergic disease is allergic rhinitis, bronchial asthma, allergic conjunctivitis, eczema, hives (Urticaria) (Nestorović et al. 2011). Pre-school and school age children are especially vulnerable and increasing the number of those who suffer from allergies caused by pollen of plants. The most common allergic disease in the world is allergic rhinitis by whom in various parts of the world affects $10-25 \%$ of the population, with a high representation of preschool and school-age children and adolescents (Nestorović et al. 2011).

Invasive woody species could threaten biodiversity and disturb aesthetics of the green kindergarten's area by sudden and quick spreading.

The aim of this research is the insight into the composition and characteristics of the existing woody species on the areas of chosen kindergartens in Belgrade. The research has included the survey of the main elements of tree growth, as well as the assessment of vitality and decorativeness of each tree on the chosen areas. The number of invasive and allergenic plant species has been established on every study area.

\section{MATERIAL AND METHODS}

The research has been conducted on the green areas of four public kindergartens in Belgrade. Those areas where the study surfaces are located were chosen randomly in different parts of the city. The kindergarten „Suncokreti“ is located in the eastern part of Belgrade. In the southern part of Belgrade, the kindergarten „Gorica“is located. The kindergarten „Nevena“ is situated in the western part of Belgrade. The research has also been conducted on the green area of the kindergarten „Ježurko“, in the northern part of the city.

Determination of the woody species has been conducted according to Vukićević (1996). The height of a tree (h) has been determined by Blume-Leis' altimeter according to Banković and Pantić (2006). The diameter of a tree (d) has 
been measured by millimetre cross traverse crisscross in two directions under the right angle at the chest height of $1.30 \mathrm{~m}$. The height of a trunk (b) has been determined by a meter or Blume-Leis' altimeter. The survey of the width of a treetop (ld) has been conducted by a ribbon in two directions under the right angle (Stavretović et al. 2010).

Besides the aforementioned parameters, the vitality and decorativeness of each tree have been assessed according to the method Stavretović et al. (2010). The assessment of vitality of every single tree has been conducted according to the following principle: the mark 1 is given to the dry tree or the tree with obviously present signs of illness and damage to a large extent. The mark 2 is given to the tree which possesses visible signs of illness and damage or decay. The vital tree with a tendency of survival is given the mark 3 . The mark 4 is given to the tree that keeps good vitality and possesses signs of illness or damage to a slight extent. Healthy, exceptionally vital tree without any visible signs of illness and damage is given the mark 5 .

The marks for decorativeness have been formed according to the following principle. The tree without any decorative characteristics has been given the mark 1 . The mark 2 has been given to the tree which possesses very few decorative characteristics; whereas the mark 3 is given to the tree which appearance has certain flaws. The mark 4 is given to the tree with very good decorative characteristics which possesses certain flaws to a slight extent. The tree with exceptional decorative values, which habitus does not possess visible flaws is given the mark 5 .

The obtained data have been processed in the statistical program SPSS Statistics 17.0. Descriptive statistical analysis has been given for every researched area: mean value $(\bar{x})$; middle error of the arithmetic mean $\left(S_{\bar{x}}\right)$, coefficient of variation (cv \%), the relation between mean values of species (\%).

Allergenic species have been determined according to Igić et al. (2008). Recorded allergenic woody species have been divided into species which allergenic characteristic of pollen are as follow: 1 . very slightly conspicuous, 2 . slightly conspicuous, 3 . moderate, 4 . moderate to strongly conspicuous, 5 . very strongly conspicuous (D'amato et al. 2007, Nestorović et al. 2011). Invasive plant species have been defined according to Vrbničanin et al. (2004) and Borišić et al. (2007).

\section{RESULTS AND DISCUSSION}

The total number of 41 woody species with 359 trees has been recorded on those four study areas. One invasive species with the total number of 38 trees $(10.6 \%)$ is present. 12 allergenic species with 133 trees have been ascertained, which is $37.0 \%$ of the total number.

The total number of 11 species with 36 trees has been recorded on the green area of the kindergarten "Ježurko". The approximate area of green space of this kindergarten is about $600 \mathrm{~m}^{2}$. The majority of trees on this area are relatively young, which is showed by the values of diameters and heights in the Table 1 . 
Table 1. Average values of the analysed characters of trees in Kindergarten „Ježurko“

\begin{tabular}{|c|c|c|c|c|c|c|c|c|c|c|c|c|c|c|c|c|c|}
\hline & & & & (cm) & & & & (m) & & & & (m) & & & & (m) & \\
\hline $\begin{array}{c}\text { Tree } \\
\text { Species }\end{array}$ & $\begin{array}{c}\mathrm{N} \\
(\%)\end{array}$ & $\equiv$ & $5:$ & $\begin{array}{c}\mathrm{CV} \\
(\%)\end{array}$ & $\%$ & $\equiv$ & $5 ;$ & $\begin{array}{c}\mathrm{CV} \\
(\%)\end{array}$ & $\%$ & $\bar{z}$ & $5 ;$ & $\begin{array}{l}\mathrm{CV} \\
(\%)\end{array}$ & $\%$ & $\bar{z}$ & s: & $\begin{array}{c}\mathrm{CV} \\
(\%)\end{array}$ & $\%$ \\
\hline $\begin{array}{l}\text { Fraxinus } \\
\text { ornus L. }\end{array}$ & 3 & 32,4 & I & 1 & 203,8 & 10,4 & I & I & 123,8 & 1,8 & I & I & 100,0 & 5,3 & I & I & 151,4 \\
\hline $\begin{array}{c}\text { Platanus } \\
\text { orientalis } \\
\text { L. }\end{array}$ & 3 & 7 & I & I & 44,0 & 6,3 & I & I & 75,0 & 1,7 & I & I & 94,4 & 2,3 & I & I & 65,7 \\
\hline $\begin{array}{c}\text { Platanus } \\
\text { acerifolia } \\
\text { (Ait.) } \\
\text { Wild. }\end{array}$ & 31 & 7,8 & 1,0 & 43,1 & 49,1 & 6,6 & 0,7 & 36,7 & 78,6 & 1,8 & 0,1 & 12,0 & 100,0 & 2,8 & 0,3 & 41,0 & 80,0 \\
\hline $\begin{array}{c}\text { Pirus } \\
\text { communis } \\
\text { L. }\end{array}$ & 3 & 6,7 & / & I & 42,1 & 3,5 & I & I & 41,7 & 1,3 & I & I & 72,2 & 1,8 & / & I & 51,4 \\
\hline $\begin{array}{c}\text { Prunus } \\
\text { cerasifera } \\
\text { Ehrh. }\end{array}$ & 3 & 8,0 & / & I & 50,3 & 2,5 & I & I & 29,8 & 1,3 & I & I & 72,2 & 1,2 & / & I & 34,3 \\
\hline $\begin{array}{c}\text { Thuja } \\
\text { orientalis } \\
\text { L. }\end{array}$ & 37 & 1,6 & 0,4 & 91,1 & 10,1 & 1,8 & 0,3 & 64,9 & 21,4 & 0 & 0 & 0 & 0,0 & 0,7 & 0,05 & 23,6 & 20,0 \\
\hline $\begin{array}{c}\text { Larix } \\
\text { decidua } \\
\text { Mill. }\end{array}$ & 5,5 & 17,3 & 7,4 & 60,5 & 108,8 & 13 & 0 & 0 & 154,8 & 2,6 & 0,2 & 13,3 & 144,4 & 4,4 & 0 & 0 & 125,7 \\
\hline $\begin{array}{c}\text { Picea } \\
\text { abies } \\
\text { Karst. }\end{array}$ & 3 & 5,2 & / & I & 32,7 & 5,3 & I & I & 63,1 & 0 & I & I & 0,0 & 1,6 & I & I & 45,7 \\
\hline \begin{tabular}{|c|} 
Acer \\
platanoides \\
L. \\
\end{tabular} & 5,5 & 21,4 & 18,3 & 121,0 & 134,6 & 9,8 & 5,6 & 81,1 & 116,7 & 3 & 1,1 & 51,9 & 166,7 & 3,8 & 2,3 & 85,6 & 108,6 \\
\hline $\begin{array}{c}\text { Quercus } \\
\text { borealis } \\
\text { Michx. }\end{array}$ & 3 & 50,1 & / & I & 315,1 & 20 & I & I & 238,1 & 3,5 & / & I & 194,4 & 9 & / & I & 257,1 \\
\hline $\begin{array}{c}\text { Betula } \\
\text { pendula } \\
\text { Roth. }\end{array}$ & 3 & 17,4 & / & I & 109,4 & 13 & I & I & 154,8 & 2,5 & / & I & 138,9 & 5,1 & I & I & 145,7 \\
\hline Average & & 15,9 & 6,8 & 78,9 & 100 & 8,4 & 1,6 & 45,7 & 100 & 1,8 & 0,3 & 19,3 & 100 & 3,5 & 0,7 & 37,6 & 100 \\
\hline
\end{tabular}

The highest values of growth elements belong to the species Quercus borealis Michx. $(\mathrm{d}=50.1 \mathrm{~cm} ; \mathrm{h}=20 \mathrm{~m} ; \mathrm{b}=3.5 \mathrm{~m}$; ld $=9 \mathrm{~m})$, whereas the lowest recorded values belong to the species Thuja orientalis $\mathrm{L} .(\mathrm{d}=1.6 \mathrm{~cm} ; \mathrm{h}=1.8 \mathrm{~m}$; ld $=0.7 \mathrm{~m}$ ). There has been noticed that the tree of the species Pirus commmunis L. possesses certain flaws, so it has been given the mark 3 for vitality and decorativeness in accordance with that. As all the other trees have been given the high evaluation for vitality and decorativeness (marks 4 and 5) it can be concluded that the species Pirus communis L. possesses the lowest evaluation for vitality and decorativeness on this area (table 2). 
Table 2. Average values of vitality and decorativeness of trees in Kindergarten „Ježurko“

\begin{tabular}{|c|c|c|c|c|c|c|c|c|c|}
\hline \multicolumn{1}{|c|}{} & \multicolumn{5}{|c|}{ VIT } & \multicolumn{4}{c|}{ DEK } \\
\hline $\begin{array}{c}\text { Tree } \\
\text { Species }\end{array}$ & $\mathrm{N}(\%)$ & $\overline{\mathrm{m}}$ & $\mathrm{s} ;$ & $\begin{array}{c}\mathrm{cV} \\
(\%)\end{array}$ & $\%$ & $\overline{5}$ & $\begin{array}{c}\mathrm{cV} \\
(\%)\end{array}$ & $\%$ \\
\hline $\begin{array}{c}\text { Fraxinus } \\
\text { ornus L. }\end{array}$ & 3 & 4 & $/$ & $/$ & 93,0 & 5 & $/$ & $/$ & 113,6 \\
\hline $\begin{array}{c}\text { Platanus orientalis L. } \\
\text { Platanus acerifolia } \\
\text { (Ait.)Wild. }\end{array}$ & 31 & 4,91 & 0,1 & 6,1 & 114,2 & 4,91 & 0,1 & 6,1 & 111,6 \\
\hline Pirus communis L. & 3 & 3 & $/$ & $/$ & 69,8 & 3 & $/$ & $/$ & 68,2 \\
\hline $\begin{array}{c}\text { Prunus cerasifera } \\
\text { Ehrh. }\end{array}$ & 3 & 4 & $/$ & $/$ & 93,0 & 4 & $/$ & $/$ & 90,9 \\
\hline Thuja orientalis L. & 37 & 4,54 & 0,1 & 11,4 & 105,6 & 4,77 & 0,1 & 9,2 & 108,4 \\
\hline Larix decidua Mill. & 5,5 & 4 & 0 & 0 & 93,0 & 4 & 0 & 0 & 90,9 \\
\hline Picea abies Karst. & 3 & 5 & $/$ & $/$ & 116,3 & 5 & $/$ & $/$ & 113,6 \\
\hline Acer platanoides L. & 5,5 & 4,5 & 0,5 & 15,7 & 104,7 & 5 & 0 & 0 & 113,6 \\
\hline $\begin{array}{c}\text { Quercus borealis } \\
\text { Michx. }\end{array}$ & 3 & 4 & $/$ & $/$ & 93,0 & 4 & $/$ & $/$ & 90,9 \\
\hline $\begin{array}{c}\text { Betula pendula } \\
\text { Roth. }\end{array}$ & 3 & 4 & $/$ & $/$ & 93,0 & 4 & $/$ & $/$ & 90,9 \\
\hline Average & 4,3 & 0,2 & 8,3 & 100 & 4,4 & 0,05 & 3,8 & 100 \\
\hline
\end{tabular}

Out of the 11 recorded species, 5 possess allergenic characteristics of pollen to a certain extent. The species Betula pendula Roth. is characterized by very strongly expressed allergenic characteristics of pollen. One tree of this species has been recorded on the researched area. The species Acer platanoides L. - 2 trees and Thuja orientalis L. - 13 trees have moderately conspicuous allergenic characteristics of pollen. The species Fraxinus ornus L. - 1 tree, Platanus $x$ acerifolia (Ait.) Willd. - 11 trees have very weakly expressed allergenic characteristics of pollen. The trees of the species Thuja orientalis L. and Platanus $x$ acerifolia (Ait.) Willd. are relatively young, so their characteristics of pollen are going to achieve its full potential in the years to come.

The invasive woody species are not present on this green area either, but they are present in the surroundings; the species Ailanthus altissima (Mill.) Svingle and Robinia pseudoacacia L., which are well known for their invasive character, have been noticed on the green surfaces in the nearby residential area.

The kindergarten "Nevena" is situated in the western part of Belgrade. The approximate area of green space of this kindergarten is about $2000 \mathrm{~m}^{2} .13$ species with the total number of 40 trees is present in its garden. The values obtained from the measured parameters are given in the table 3 . The highest recorded values belong to the species Cedrus deodara $($ Rohb $) \mathrm{G}$. Don. $(\mathrm{d}=36.3 \mathrm{~cm} ; \mathrm{h}=$ $15.5 \mathrm{~m}$; $\mathrm{ld}=6.9 \mathrm{~m})$ and Tilia argentea $\mathrm{DC} .(\mathrm{d}=37.4 \mathrm{~cm} ; \mathrm{h}=8.5 \mathrm{~m}$; $\mathrm{ld}=5.1 \mathrm{~m})$. 
The lowest recorded values $(\mathrm{d}=1.2 \mathrm{~cm} ; \mathrm{h}=1.4 \mathrm{~m}$; $\mathrm{ld}=0.6 \mathrm{~m})$ belong to the species Pseudotsuga menziesii (Mirb.)Franco. which stems from the fact that the trees of this species are very young. The trees on this green area are given the highest assessments for their vitality and decorativeness (table 4). The species of Thuja orientalis L., Picea abies Karst., Picea orientalis Link. are characterized with the lowest assessments for vitality and decorativeness of the trees (mark 3 ).

Allergenic characteristics of pollen are predominant to a certain extent in 6 of the total amount of 13 recorded species. The species Tilia argentea DC is present with the only one tree on this area. Allergenic characteristics of pollen of this species are moderately to strongly conspicuous. There has also been noted the presence of two species with moderately expressed allergenic characteristics of pollen (Acer platanoides L. and Thuja orientalis L. with one specimen each). The species Pinus nigra Arn.- 3 trees, Cedrus atlantica (Endl.)Man ex Carr - 3 trees and Abies concolor Lindl. et Gord - 3 trees are characterised with weakly conspicuous allergenic effect of pollen.

Table 3. Average values of the analysed characters of trees in Kindergarten „Nevena“

\begin{tabular}{|c|c|c|c|c|c|c|c|c|c|c|c|c|c|c|c|c|c|}
\hline & & \multicolumn{4}{|c|}{$\mathrm{d}(\mathrm{cm})$} & \multicolumn{4}{|c|}{ h (m) } & \multicolumn{4}{|c|}{$\mathrm{b}(\mathrm{m})$} & \multicolumn{4}{|c|}{ ld (m) } \\
\hline $\begin{array}{c}\text { Tree } \\
\text { Species }\end{array}$ & $\begin{array}{l}\mathrm{N} \\
(\%)\end{array}$ & $\equiv$ & s; & $\begin{array}{l}\mathrm{CV} \\
(\%)\end{array}$ & $\%$ & $\equiv$ & s; & $\begin{array}{l}\mathrm{CV} \\
(\%)\end{array}$ & $\%$ & $\overline{\#}$ & s; & \begin{tabular}{|c}
$\mathrm{CV}$ \\
$(\%)$
\end{tabular} & $\%$ & $\bar{\Sigma}$ & $5 ;$ & $\begin{array}{l}\mathrm{cv} \\
\text { (\%) }\end{array}$ & $\%$ \\
\hline Pinus nigra Arn. & 7,5 & 15,0 & 0,3 & 3,7 & 95,5 & 6,6 & 1,0 & 25,5 & 110,0 & 1,6 & 0,06 & 6,2 & 114,3 & 2,4 & 0,2 & 12,6 & 88,9 \\
\hline $\begin{array}{l}\text { Cedrus atlantica } \\
\text { (Endl.)Man. Ex } \\
\text { Carr. }\end{array}$ & 12,5 & 23,5 & 10,2 & 97,2 & 149,7 & 7,7 & 2,7 & 77,0 & 128,3 & 0,9 & 0,4 & 91,7 & 64,3 & 4,1 & 1,3 & 72,2 & 151,9 \\
\hline $\begin{array}{c}\text { Prunus cerasifera } \\
\text { Atropurpurea } \\
\text { Ehrh. }\end{array}$ & 40 & 12,1 & 2,6 & 86,9 & 77,1 & 5,8 & 0,8 & 53,9 & 96,7 & 2 & 0,04 & 8,2 & 142,9 & 3,1 & 0,7 & 87,9 & 114,8 \\
\hline $\begin{array}{l}\text { Picea orientalis } \\
\text { Linkp. }\end{array}$ & 2,5 & 16,1 & I & I & 102,5 & 4,5 & I & I & 75,0 & 2 & I & I & 142,9 & 1,6 & l & I & 59,3 \\
\hline Picea abies Karst. & 2,5 & 6,9 & 1 & 1 & 43,9 & 2 & 1 & 1 & 33,3 & 0 & l & 1 & 0,0 & 1,5 & 1 & 1 & 55,6 \\
\hline $\begin{array}{l}\text { Ulmus effusa } \\
\text { Willp. }\end{array}$ & 2,5 & 11,9 & 1 & I & 75,8 & 7,2 & I & I & 120,0 & 1,7 & I & I & 121,4 & 3,3 & I & I & 122,2 \\
\hline $\begin{array}{c}\text { Thuja orientalis } \\
\text { L. }\end{array}$ & 2,5 & 18 & I & l & 114,6 & 6,5 & l & I & 108,3 & 1,5 & I & I & 107,1 & 1,6 & l & I & 59,3 \\
\hline $\begin{array}{l}\text { Abies concolor } \\
\text { Lindl. et Gord. }\end{array}$ & 7,5 & 7,3 & 0,8 & 17,7 & 46,5 & 3,2 & 0,7 & 36,5 & 53,3 & 0 & 0 & 0 & 0 & 1,4 & 0,09 & 11,2 & 51,9 \\
\hline $\begin{array}{l}\text { Pseudotsuga } \\
\text { menziesii } \\
\text { (Mirb.)Franco }\end{array}$ & 7,5 & 1,2 & 0,1 & 21,6 & 7,6 & 1,4 & 0,2 & 29,6 & 23,3 & 0 & 0 & 0 & 0 & 0,6 & 0,2 & 50,8 & 22,2 \\
\hline $\begin{array}{l}\text { Acer platanoides } \\
\text { L. }\end{array}$ & 2,5 & 15,4 & I & I & 98,1 & 5,5 & I & I & 91,7 & 2 & I & I & 142,9 & 2,1 & I & 1 & 77,8 \\
\hline $\begin{array}{c}\text { Tilia argentea } \\
\text { DC. }\end{array}$ & 2,5 & 37,4 & I & I & 238,2 & 8,5 & I & I & 141,7 & 2,1 & I & I & 150,0 & 5,1 & I & I & 188,9 \\
\hline Celtis australis L. & 7,5 & 2,7 & 0,2 & 15,2 & 17,2 & 3,8 & 0,2 & 9,1 & 63,3 & 2,3 & 0,03 & 2,5 & 164,3 & 1,6 & 0,07 & 7,4 & 59,3 \\
\hline $\begin{array}{l}\text { Cedrus deodara } \\
\text { (Roxb.)Don }\end{array}$ & 2,5 & 36,3 & 1 & l & 231,2 & 15,5 & 1 & I & 258,3 & 1,5 & I & I & 107,1 & 6,9 & I & I & 255,6 \\
\hline Average & & 15,7 & 2,4 & 40,4 & 100 & 6,0 & 0,9 & 38,6 & 100 & 1,4 & 0,09 & 18,1 & 100 & 2,7 & 0,4 & 40,3 & 100 \\
\hline
\end{tabular}


Table 4. Average values of vitality and decorativeness of trees in Kindergarten „Nevena“

\begin{tabular}{|c|c|c|c|c|c|c|c|c|c|}
\hline & & \multicolumn{4}{|c|}{ VIT } & \multicolumn{4}{|c|}{ DEK } \\
\hline $\begin{array}{c}\text { Tree } \\
\text { Species }\end{array}$ & $\mathrm{N}(\%)$ & $\equiv$ & s; & $\begin{array}{l}\mathrm{CV} \\
(\%)\end{array}$ & $\%$ & $\equiv$ & s; & $\begin{array}{l}\mathrm{CV} \\
(\%)\end{array}$ & $\%$ \\
\hline Pinus nigra Arn. & 7,5 & 4 & 0 & 0 & 93,0 & 4 & 0 & 0 & 90,9 \\
\hline $\begin{array}{l}\text { Cedrus atlantica } \\
\text { (Endl.)Man. Ex Carr. }\end{array}$ & 12,5 & 4,6 & 0,2 & 11,9 & 107,0 & 4,8 & 0,2 & 9,3 & 109,1 \\
\hline $\begin{array}{l}\text { Prunus cerasifera } \\
\text { Atropurpurea Ehrh. }\end{array}$ & 40 & 4,1 & 0,2 & 22,9 & 95,3 & 4,1 & 0,2 & 23,2 & 93,2 \\
\hline $\begin{array}{l}\text { Picea orientalis } \\
\text { Linkp. }\end{array}$ & 2,5 & 3 & I & I & 69,8 & 3 & I & I & 68,2 \\
\hline Picea abies Karst. & 2,5 & 3 & 1 & 1 & 69,8 & 3 & 1 & 1 & 68,2 \\
\hline Ulmus effusa Willp. & 2,5 & 4 & 1 & 1 & 93,0 & 5 & 1 & 1 & 113,6 \\
\hline Thuja orientalis L. & 2,5 & 3 & 1 & 1 & 69,8 & 3 & 1 & 1 & 68,2 \\
\hline $\begin{array}{l}\text { Abies concolor } \\
\text { Lindl. et Gord. }\end{array}$ & 7,5 & 5 & 0 & 0 & 116,3 & 5 & 0 & 0 & 113,6 \\
\hline $\begin{array}{l}\text { Pseudotsuga menziesii } \\
\text { (Mirb.)Franco }\end{array}$ & 7,5 & 5 & 0 & 0 & 116,3 & 5 & 0 & 0 & 113,6 \\
\hline Acer platanoides L. & 2,5 & 5 & 1 & 1 & 116,3 & 5 & I & 1 & 113,6 \\
\hline Tilia argentea DC. & 2,5 & 5 & 1 & 1 & 116,3 & 5 & 1 & 1 & 113,6 \\
\hline Celtis australis L. & 7,5 & 5 & 0 & 0 & 116,3 & 5 & 0 & 0 & 113,6 \\
\hline $\begin{array}{l}\text { Cedrus deodara } \\
\text { (Roxb.) Don }\end{array}$ & 2,5 & 5 & I & I & 116,3 & 5 & I & I & 113,6 \\
\hline Average & & 4,3 & 0,07 & 5,8 & 100 & 4,4 & 0,07 & 5,4 & 100 \\
\hline
\end{tabular}

The invasive woody species on this green area have not been noticed. Invasive woody species like Robinia pseudoacacia L. are present in the close surroundings of the kindergarten, in the residential area.

The kindergarten "Gorica" is located in southern part of Belgrade. The approximate area of green space of this kindergarten is about $7500 \mathrm{~m}^{2}$. The presence of 17 species with the total number of 52 trees has been recorded on this green area. The table 5. presents the measured parameters for every species: the diameter of a tree (d), the height of a tree (h), the width of a treetop (ld), the height of a trunk (b). Species like Cedrus atlantica (Endl.) Man. ex Carr., Thuja giganthea Nutt., Abies concolor Lindl. et Gord. characterize with the highest values of diameters and heights of the trees. The highest evaluations of vitality and decorativeness (table 6) have been granted to the trees of the species Acer platanoides L. (VIT $=5$; DEK $=5$ ) and Cedrus atlantica (Endl.) Man. ex Carr. (VIT= 4.5; DEK= 4.9). The species Cedrus atlantica (Endl.) Man. ex Carr is present with the total number of 8 trees, which is the most numerous on this area. The lowest measured values of growth elements $(\mathrm{d}=0.6 \mathrm{~cm} ; \mathrm{h}=0.4 \mathrm{~m}$; ld $=$ $0.3 \mathrm{~m}$ ) belong to the species of Thuja orientalis L. It is necessary to indicate that all the individual trees of the aforementioned species are very young, recently planted, which explains given low values. However, this species has been credited with the high evaluation of vitality and decorativeness (VIT $=4$; DEK = 4). 
Table 5. Average values of the analysed characters of trees in Kindergarten „Gorica“

\begin{tabular}{|c|c|c|c|c|c|c|c|c|c|c|c|c|c|c|c|c|c|}
\hline & & & & (cm) & & & & (m) & & & & (m) & & & ld (m & & \\
\hline $\begin{array}{c}\text { Tree } \\
\text { Species }\end{array}$ & N (\%) & $i$ & $x_{z}$ & $\begin{array}{l}\mathrm{CV} \\
(\%)\end{array}$ & $\%$ & $\pi$ & $x_{2}$ & $\begin{array}{l}\mathrm{CV} \\
(\%)\end{array}$ & $\%$ & i & $x_{z}$ & $\begin{array}{l}\mathrm{cV} \\
(\%)\end{array}$ & $\%$ & $\pi$ & $x_{A}$ & $\begin{array}{l}\mathrm{CV} \\
(\%)\end{array}$ & $\%$ \\
\hline $\begin{array}{c}\text { Acer } \\
\text { platanoides L. }\end{array}$ & 2 & 17,9 & I & I & 210,6 & 4,5 & I & I & 121,6 & 1,9 & I & I & 82,6 & 1,9 & I & I & 135,7 \\
\hline $\begin{array}{c}\text { Quercus } \\
\text { borealis Ten. }\end{array}$ & 2 & 3,4 & I & I & 40,0 & 4 & 1 & I & 108,1 & 3 & I & I & 130,4 & 0,5 & I & I & 35,7 \\
\hline $\begin{array}{c}\text { Cedrus atlantica } \\
\text { (Endl.) Man. Ex } \\
\text { Carr. }\end{array}$ & 15 & 18,1 & 8,0 & 125,7 & 212,9 & 6,8 & 2,0 & 85,6 & 183,8 & 0,6 & 0,3 & 142,7 & 26,1 & 2,9 & 0,8 & 76,6 & 207,1 \\
\hline $\begin{array}{c}\text { Pseudotsuga } \\
\text { menziesii } \\
\text { (Mirb.) Franco }\end{array}$ & 7 & 13,4 & 6,6 & 97,7 & 157,6 & 5,7 & 2,4 & 85,3 & 154,1 & 0,9 & 0,5 & 115,8 & 39,1 & 2,2 & 0,9 & 81,8 & 157,1 \\
\hline $\begin{array}{c}\text { Betula pendula } \\
\text { Roth. }\end{array}$ & 6 & 14,2 & 7,4 & 89,4 & 167,1 & 5,2 & 1,7 & 57,0 & 140,5 & 1,4 & 0,4 & 54,9 & 60,9 & 2,6 & 0,6 & 42,8 & 185,7 \\
\hline $\begin{array}{c}\text { Koelreuteria } \\
\text { paniculata } \\
\text { Laxm. }\end{array}$ & 9 & 3,5 & 0,08 & 5,2 & 41,2 & 3,2 & 0,2 & 13,3 & 86,5 & 1,1 & 0,04 & 7,7 & 47,8 & 1,3 & 0,05 & 9,0 & 92,9 \\
\hline $\begin{array}{c}\text { Prunus } \\
\text { cerasifera } \text { Ehrh. }\end{array}$ & 2 & 1,9 & I & 1 & 22,4 & 2,5 & 1 & I & 67,6 & 1,9 & I & 1 & 82,6 & 0,6 & I & I & 42,9 \\
\hline $\begin{array}{c}\text { Pinus nigra } \\
\text { Arn. }\end{array}$ & 9 & 4,3 & 0,4 & 23,5 & 50,6 & 1,9 & 0,3 & 32,8 & 51,4 & 0 & 0 & 0 & 0,0 & 1,3 & 0,2 & 32,4 & 92,9 \\
\hline $\begin{array}{c}\text { Sorbus scandica } \\
\text { Fries. }\end{array}$ & 2 & 2,4 & I & I & 28,2 & 2,5 & I & I & 67,6 & 2,1 & I & I & 91,3 & 0,6 & / & I & 42,9 \\
\hline $\begin{array}{c}\text { Thuja gigantea } \\
\text { Nutt. }\end{array}$ & 2 & 25,5 & I & I & 300,0 & 7,5 & 1 & I & 202,7 & 1,9 & I & 1 & 82,6 & 2,3 & I & I & 164,3 \\
\hline \begin{tabular}{|c} 
Thuja orientalis \\
L.
\end{tabular} & 4 & 0,6 & 0,1 & 23,6 & 7,1 & 0,4 & 0 & 0 & 10,8 & 0 & 0 & 0 & 0,0 & 0,3 & 0 & 0 & 21,4 \\
\hline Prunus avium L. & 2 & 0,8 & I & I & 9,4 & 1,5 & I & I & 40,5 & 1,3 & I & I & 56,5 & 0,2 & I & I & 14,3 \\
\hline \begin{tabular}{|c|} 
Acer \\
pseudoplatanus \\
L.
\end{tabular} & 2 & 3,6 & l & I & 42,4 & 2,3 & / & l & 62,2 & 1,9 & 1 & 1 & 82,6 & 0,8 & / & / & 57,1 \\
\hline $\begin{array}{l}\text { Abies concolor } \\
\text { Lindl. et Gord. }\end{array}$ & 7 & 18,3 & 5,7 & 61,9 & 215,3 & 6,4 & 1,7 & 52,2 & 173,0 & 1,1 & 0,4 & 67,1 & 47,8 & 2,4 & 0,3 & 26,8 & 171,4 \\
\hline $\begin{array}{l}\text { Picea pungens } \\
\text { Engelm. }\end{array}$ & 6 & 1,2 & 0,2 & 23,4 & 14,1 & 1,5 & 1,0 & 115,5 & 40,5 & 0 & 0 & 0 & 0,0 & 0,6 & 0,3 & 81,5 & 42,9 \\
\hline $\begin{array}{c}\text { Tilia argentea } \\
\text { DC. }\end{array}$ & 17 & 13,0 & 2,2 & 51,1 & 152,9 & 5,7 & 0,6 & 29,3 & 154,1 & 1,8 & 0,04 & 5,8 & 78,3 & 3,2 & 0,4 & 36,2 & 228,6 \\
\hline $\begin{array}{c}\text { Picea abies } \\
\text { Karst. }\end{array}$ & 6 & 2,8 & 2,1 & 129,4 & 32,9 & 1,5 & 1,0 & 115,5 & 40,5 & 0 & 0 & 0 & 0,0 & 0,6 & 0,3 & 81,5 & 42,9 \\
\hline Average & & 8,5 & 3,3 & 63,1 & 100 & 3,7 & 1,1 & 58,6 & 100 & 2,3 & 0,2 & 39,4 & 100 & 1,4 & 0,4 & 46,9 & 100 \\
\hline
\end{tabular}

Out of the total number of 17 species recorded, 8 species possess allergenic characteristics. The species Betula pendula Roth. possesses very conspicuous allergenic characteristics of pollen and it is present on this green area with 3 trees. The species of the genus Tilia spp., which allergenic characteristics are moderately to strongly expressed, have the total number of 7 trees. Two species (Acer platanoides L. - 1 tree, Thuja orientalis L.- 2 trees) have moderately expressed characteristics of pollen. Four species (Cedrus atlantica 
(Endl.) Man. ex Carr - 8 trees, Pinus nigra Arn. - 5 trees, Abies concolor Lindl. et Gord. - 4 trees, Acer pseudoplatanus L. - 1 tree) have weakly expressed allergenic characteristics of pollen.

Invasive woody species have not been recorded on this area, even though they are present in the surroundings of the kindergarten. The presence of the species Ailanthus altissima (Mill.) Svingle, Robinia pseudoacacia L.as well as Acer negundo L. has also been noticed.

Table 6. Average values of vitality and decorativeness of trees in Kindergarten „Gorica“

\begin{tabular}{|c|c|c|c|c|c|c|c|c|c|}
\hline & & \multicolumn{4}{|c|}{ VIT } & \multicolumn{4}{|c|}{ DEK } \\
\hline $\begin{array}{c}\text { Tree } \\
\text { Species }\end{array}$ & N (\%) & $\equiv$ & $5 ;$ & $\begin{array}{l}\mathrm{CV} \\
(\%)\end{array}$ & $\%$ & $\bar{z}$ & $5 ;$ & $\begin{array}{l}\mathrm{CV} \\
(\%)\end{array}$ & $\%$ \\
\hline Acer platanoides L. & 2 & 5 & / & / & 128,2 & 5 & / & / & 122,0 \\
\hline Quercus borealis Ten. & 2 & 4 & / & l & 102,6 & 3 & / & / & 73,2 \\
\hline $\begin{array}{c}\text { Cedrus atlantica } \\
\text { (Endl.) Man. Ex Carr. }\end{array}$ & 15 & 4,5 & 0,3 & 16,8 & 115,4 & 4,9 & 0,1 & 7,3 & 119,5 \\
\hline $\begin{array}{l}\text { Pseudotsuga menziesii } \\
\text { (Mirb.) Franco }\end{array}$ & 7 & 4,2 & 0,2 & 11,8 & 107,7 & 4,5 & 0,3 & 12,8 & 109,8 \\
\hline Betula pendula Roth. & 6 & 4 & 0 & 0 & 102,6 & 4,3 & 0,3 & 13,3 & 104,9 \\
\hline $\begin{array}{c}\text { Koelreuteria paniculata } \\
\text { Laxm. }\end{array}$ & 9 & 3,6 & 0,2 & 15,2 & 92,3 & 3,8 & 0,2 & 11,8 & 92,7 \\
\hline Prunus cerasifera Ehrh. & 2 & 4 & / & / & 102,6 & 4 & / & l & 97,6 \\
\hline Pinus nigra Arn. & 9 & 4 & 0 & 0 & 102,6 & 4 & 0 & 0 & 97,6 \\
\hline Sorbus scandica Fries. & 2 & 3 & / & / & 76,9 & 4 & / & / & 97,6 \\
\hline Thuja gigantea Nutt. & 2 & 3 & / & / & 76,9 & 4 & / & / & 97,6 \\
\hline Thuja orientalis L. & 4 & 4 & 0 & 0 & 102,6 & 4 & 0 & 0 & 97,6 \\
\hline Prunus avium L. & 2 & 4 & / & / & 102,6 & 4 & / & / & 97,6 \\
\hline Acer pseudoplatanus L. & 2 & 4 & / & / & 102,6 & 4 & / & / & 97,6 \\
\hline $\begin{array}{l}\text { Abies concolor Lindl. et } \\
\text { Gord. }\end{array}$ & 7 & 3,5 & 0,3 & 16,5 & 89,7 & 4 & 0 & 0 & 97,6 \\
\hline Picea pungens Engelm. & 6 & 4 & 0,6 & 25,0 & 102,6 & 4 & 0,6 & 25,0 & 97,6 \\
\hline Tilia argentea DC. & 17 & 3,7 & 0,2 & 13,6 & 94,9 & 4,1 & 0,1 & 8,1 & 100,0 \\
\hline Picea abies Karst. & 6 & 4 & 0,6 & 25,0 & 102,6 & 4 & 0,6 & 25,0 & 97,6 \\
\hline Average & & 3,9 & 0,2 & 12,4 & 100 & 4,1 & 0,2 & 10,3 & 100 \\
\hline
\end{tabular}

The kindergarten "Suncokreti" is located in the eastern part of Belgrade. The approximate area of green space of this kindergarten is about $11000 \mathrm{~m}^{2}$. The total number of 26 species with 227 trees has been recorded on the green area which belongs to the kindergarten. The maximum values of the elements of growth (table 7) belong to the species Quercus virgiliana Ten. $(\mathrm{d}=41.2 \mathrm{~cm} ; \mathrm{h}=$ $13.5 \mathrm{~m} ; \mathrm{b}=1.5 \mathrm{~m}$; ld $=9.2 \mathrm{~m})$ and Liriodendron tulipifera $\mathrm{L} .(\mathrm{d}=38.5 \mathrm{~cm} ; \mathrm{h}=$ $22.5 \mathrm{~m} ; \mathrm{b}=2.8 \mathrm{~m}$; $\mathrm{ld}=11.1 \mathrm{~m})$, whereas the minimum values have been recorded at the species of Fraxinus angustifolia Vahl. $(\mathrm{d}=2.4 \mathrm{~cm} ; \mathrm{h}=3.1 \mathrm{~m} ; \mathrm{b}=1.3 \mathrm{~m}$; ld $=$ $2.3 \mathrm{~m})$ and Malus domestica Borkh. $(\mathrm{d}=4.4 \mathrm{~cm} ; \mathrm{h}=2.5 \mathrm{~m} ; \mathrm{b}=1.5 \mathrm{~m} ; \mathrm{ld}=1.9 \mathrm{~m})$. 
Table 7. Average values of the analysed characters of trees in Kindergarten „Suncokreti“

\begin{tabular}{|c|c|c|c|c|c|c|c|c|c|c|c|c|c|c|c|c|c|}
\hline & & & & $(\mathrm{cm})$ & & & & (m) & & & & (m) & & & & (m) & \\
\hline $\begin{array}{c}\text { Tree } \\
\text { Species }\end{array}$ & $\begin{array}{c}\mathrm{N} \\
(\%)\end{array}$ & $\equiv$ & $5 ;$ & $\begin{array}{l}\mathrm{CV} \\
(\%)\end{array}$ & $\%$ & $\equiv$ & $5 ;$ & $\begin{array}{l}\mathrm{CV} \\
(\%)\end{array}$ & $\%$ & $\bar{E}$ & $5 ;$ & $\begin{array}{l}\mathrm{CV} \\
(\%)\end{array}$ & $\%$ & $\equiv$ & $5 ;$ & $\begin{array}{c}\mathrm{CV} \\
(\%)\end{array}$ & $\%$ \\
\hline Thuja orientalis L. & 0,5 & 7,6 & I & l & 48,4 & 6,5 & l & / & 74,7 & 0 & I & / & 0,0 & 2,4 & I & I & 52,2 \\
\hline $\begin{array}{l}\text { Picea pungens } \\
\text { Engelm. }\end{array}$ & 2,2 & 8,2 & 1,4 & 33,0 & 52,2 & 6,5 & 1,1 & 35,0 & 74,7 & 0,4 & 0,4 & 200 & 26,7 & 2,6 & 0,5 & 39,1 & 56,5 \\
\hline Prunus avium L. & 1,6 & 16,5 & 6,7 & 70,7 & 105,1 & 4,8 & 0,5 & 17,6 & 55,2 & 1,5 & 0,1 & 13,3 & 100,0 & 5,0 & 1,0 & 34,0 & 108,7 \\
\hline $\begin{array}{c}\text { Laburnum } \\
\text { anagyroides Med. }\end{array}$ & 2,7 & 6,2 & 0,6 & 21,4 & 39,5 & 3,6 & 0,3 & 2,16 & 41,4 & 1,5 & 0,08 & 11,8 & 100,0 & 2,0 & 0,2 & 20,2 & 43,5 \\
\hline $\begin{array}{c}\text { Prunus cerasifera } \\
\text { Atropurpurea } \\
\text { Ehrh. }\end{array}$ & 12 & 12,4 & 1,4 & 52,3 & 79,0 & 7,0 & 0,3 & 22,9 & 80,5 & 1,5 & 0,06 & 17,5 & 100,0 & 4,5 & 0,2 & 25,5 & 97,8 \\
\hline $\begin{array}{c}\text { Tilia grandifolia } \\
\text { DC. }\end{array}$ & 6 & 28,0 & 3,3 & 38,7 & 178,3 & 12,7 & 0,9 & 23,4 & 146,0 & 2 & 0,1 & 22,3 & 133,3 & 7,5 & 0,7 & 30,0 & 163,0 \\
\hline $\begin{array}{l}\text { Betula pendula } \\
\text { Roth. }\end{array}$ & 7,1 & 10,9 & 2,1 & 69,6 & 69,4 & 7,9 & 1,3 & 60,5 & 90,8 & 1,9 & 0,1 & 25,8 & 126,7 & 3,7 & 0,5 & 48,9 & 80,4 \\
\hline $\begin{array}{c}\text { Acer platanoides } \\
\text { L. }\end{array}$ & 11,4 & 20,5 & 1,3 & 29,4 & 130,6 & 12,3 & 0,4 & 13,3 & 141,4 & 1,9 & 0,06 & 13,6 & 126,7 & 6,0 & 0,5 & 35,9 & 130,4 \\
\hline $\begin{array}{c}\text { Fraxinus } \\
\text { angustifolia } \text { Vahl. }\end{array}$ & 2,2 & 2,4 & 0,4 & 36,0 & 15,3 & 3,1 & 0,6 & 36,0 & 35,6 & 1,3 & 0,2 & 29,5 & 86,7 & 2,3 & 0,4 & 36,6 & 50,0 \\
\hline $\begin{array}{c}\text { Prunus armeniaca } \\
\text { L. }\end{array}$ & 0,5 & 15,9 & / & I & 101,3 & 9 & / & / & 103,4 & 1,4 & / & l & 93,3 & 4,7 & I & I & 102,2 \\
\hline $\begin{array}{c}\text { Robinia } \\
\text { pseudoacacia L. }\end{array}$ & 20,7 & 20,5 & 0,8 & 24,6 & 130,6 & 11,9 & 0,4 & 20,9 & 136,8 & 2,1 & 0,04 & 11,0 & 140,0 & 5,8 & 0,3 & 30,2 & 126,1 \\
\hline Tilia argentea DC. & 1,1 & 28,5 & 4,4 & 22,0 & 181,5 & 14,0 & 0,5 & 5,1 & 160,9 & 1,9 & 0,5 & 37,2 & 126,7 & 7,2 & 0,1 & 2,9 & 156,5 \\
\hline $\begin{array}{c}\text { Quercus virgiliana } \\
\text { Ten. }\end{array}$ & 1,1 & 41,2 & 2,0 & 6,9 & 262,4 & 13,5 & 1,0 & 10,5 & 155,2 & 1,5 & 0,2 & 22,8 & 100,0 & 9,2 & 0,4 & 6,9 & 200,0 \\
\hline $\begin{array}{c}\text { Catalpa } \\
\text { bignonioides Walt. }\end{array}$ & 3,8 & 9,9 & 0,9 & 22,9 & 63,1 & 8,7 & 0,7 & 20,6 & 100,0 & 1,7 & 0,08 & 12,5 & 113,3 & 3,9 & 0,3 & 22,1 & 84,8 \\
\hline $\begin{array}{c}\text { Cercis } \\
\text { siliquastrum L. }\end{array}$ & 2,2 & 8,9 & 0,6 & 14,5 & 56,7 & 4,1 & 0,1 & 6,1 & 47,1 & 1,5 & 0 & 0 & 100,0 & 2,7 & 0,07 & 5,6 & 58,7 \\
\hline Acer campestre L. & 2,2 & 26,8 & 2,7 & 20,3 & 170,7 & 14,2 & 1,5 & 20,8 & 163,2 & 1,7 & 0,2 & 19,2 & 113,3 & 5,9 & 0,07 & 2,4 & 128,3 \\
\hline Rhus typhina L. & 0,5 & 10,9 & 1 & l & 69,4 & 3,5 & I & I & 40,2 & 1,9 & I & l & 126,7 & 4,5 & I & I & 97,8 \\
\hline $\begin{array}{c}\text { Crataegus } \\
\text { monogyina Jacq. }\end{array}$ & 1,1 & 6,1 & 1,9 & 44,8 & 38,9 & 4,1 & 0,1 & 5,1 & 47,1 & 1,5 & 0,05 & 4,6 & 100,0 & 2,6 & 0,4 & 24,0 & 56,5 \\
\hline Juglans regia L. & 1,1 & 13,0 & 9,3 & 101,3 & 82,8 & 7,5 & 5,0 & 94,3 & 86,2 & 1,7 & 0,05 & 4,0 & 113,3 & 5,4 & 3,0 & 79,1 & 117,4 \\
\hline $\begin{array}{c}\text { Aesculus } \\
\text { hypocastanum L. }\end{array}$ & 2,2 & 12,7 & 2,6 & 41,5 & 80,9 & 7,2 & 0,7 & 19,9 & 82,8 & 1,8 & 0,02 & 2,7 & 120,0 & 3,9 & 0,7 & 33,6 & 84,8 \\
\hline $\begin{array}{l}\text { Malus domestica } \\
\text { Borkh. }\end{array}$ & 0,5 & 4,4 & / & l & 28,0 & 2,5 & l & / & 28,7 & 1,5 & l & I & 100,0 & 1,9 & / & l & 41,3 \\
\hline $\begin{array}{c}\text { Cedrus atlantica } \\
\text { (Endl.)Man. Ex } \\
\text { Carr. }\end{array}$ & 3,8 & 27,7 & 1,3 & 12,3 & 176,4 & 18,6 & 0,7 & 10,2 & 213,8 & 1,8 & 0,1 & 17,7 & 120,0 & 5,6 & 0,2 & 10,4 & 121,7 \\
\hline $\begin{array}{l}\text { Abies concolor } \\
\text { Lindl.et Gord. }\end{array}$ & 0,5 & 7,5 & / & l & 47,8 & 6,5 & / & / & 74,7 & 0 & / & / & 0,0 & 2,2 & I & / & 47,8 \\
\hline Picea abies Karst. & 1,1 & 16,3 & 0,1 & 0,9 & 103,8 & 10,4 & 0 & 0 & 119,5 & 1,4 & 0 & 0 & 93,3 & 2,1 & 0 & 0 & 45,7 \\
\hline $\begin{array}{c}\text { Liriodendron } \\
\text { tulipifera L. }\end{array}$ & 0,5 & 38,5 & l & l & 245,2 & 22,5 & l & / & 258,6 & 2,8 & / & I & 186,7 & 11,1 & I & I & 241,3 \\
\hline $\begin{array}{c}\text { Prunus } \\
\text { cerasus L. }\end{array}$ & 11,4 & 6,5 & 0,3 & 20,0 & 41,4 & 4,6 & 0,1 & 14,5 & 52,9 & 1,5 & 0,02 & 5,3 & 100,0 & 3,7 & 0,2 & 18,9 & 80,4 \\
\hline Average & & 15,7 & 2,2 & 34,2 & 100 & 8,7 & 0,8 & 21,9 & 100 & 1,5 & 0,1 & 23,5 & 100 & 4,6 & 0,5 & 25,3 & 100 \\
\hline
\end{tabular}


The tree of the species Liriodendron tulipifera L. is very vital without any visible signs of illness or damage, so it consequently got the mark 5 for its vitality and decorativeness (table 8). The trees of the species Prunus cerasus L., Laburnum anagiroides Med., Rhus typhina L.and Crataegus monogina Jacq. got the lowest marks for their vitality and decorativeness.

Table 8. Average values vitality and decorativeness of trees in Kindergarten „Suncokreti“

\begin{tabular}{|c|c|c|c|c|c|c|c|c|c|}
\hline & & & & IT & & & & $\mathrm{K}$ & \\
\hline $\begin{array}{c}\text { Tree } \\
\text { Species }\end{array}$ & $\mathrm{N}(\%)$ & $\bar{z}$ & $s ;$ & $\begin{array}{l}\mathrm{cV} \\
(\%)\end{array}$ & $\%$ & $\equiv$ & s; & $\begin{array}{l}\mathrm{cV} \\
(\%)\end{array}$ & $\%$ \\
\hline Thuja orientalis L. & 0,5 & 5 & 1 & 1 & 147,1 & 5 & 1 & 1 & 142,9 \\
\hline Picea pungens Engelm. & 2,2 & 3,2 & 0,6 & 38,7 & 94,1 & 3,2 & 0,6 & 38,7 & 91,4 \\
\hline Prunus avium L. & 1,6 & 1,7 & 0,7 & 69,3 & 50,0 & 2 & 1 & 86,6 & 57,1 \\
\hline $\begin{array}{c}\text { Laburnum anagyroides } \\
\text { Med. }\end{array}$ & 2,7 & 2 & 0 & 0 & 58,8 & 1,6 & 0,2 & 34,2 & 45,7 \\
\hline $\begin{array}{l}\text { Prunus cerasifera } \\
\text { Atropurpurea Ehrh. }\end{array}$ & 12 & 3,2 & 0,09 & 13,3 & 94,1 & 3,4 & 0,1 & 19,5 & 97,1 \\
\hline Tilia grandifolia DC. & 6 & 4,5 & 0,2 & 11,7 & 132,4 & 4,6 & 0,2 & 14,5 & 131,4 \\
\hline Betula pendula Roth. & 7,1 & 3,2 & 0,3 & 28,7 & 94,1 & 3,5 & 0,2 & 21,9 & 100,0 \\
\hline Acer platanoides $\mathrm{L}$. & 11,4 & 4,1 & 0,1 & 13,2 & 120,6 & 4,4 & 0,2 & 16,9 & 125,7 \\
\hline $\begin{array}{c}\text { Fraxinus angustifolia } \\
\text { Vahl. }\end{array}$ & 2,2 & 4 & 0 & 0 & 117,6 & 4 & 0 & 0 & 114,3 \\
\hline Prunus armeniaca L. & 0,5 & 2 & 1 & 1 & 58,8 & 1 & I & 1 & 28,6 \\
\hline $\begin{array}{l}\text { Robinia pseudoacacia } \\
\text { L. }\end{array}$ & 20,7 & 2,9 & 0,1 & 23,0 & 85,3 & 2,8 & 0,1 & 30,2 & 80,0 \\
\hline Tilia argentea DC. & 1,1 & 4 & 0 & 0 & 117,6 & 4,5 & 0,5 & 15,7 & 128,6 \\
\hline Quercus virgiliana Ten. & 1,1 & 4 & 0 & 0 & 117,6 & 4 & 0 & 0 & 114,3 \\
\hline $\begin{array}{c}\text { Catalpa bignonioides } \\
\text { Walt. }\end{array}$ & 3,8 & 3,7 & 0,3 & 20,4 & 108,8 & 4 & 0,2 & 14,4 & 114,3 \\
\hline Cercis siliquastrum L. & 2,2 & 4 & 0 & 0 & 117,6 & 4 & 0 & 0 & 114,3 \\
\hline Acer campestre $\mathrm{L}$. & 2,2 & 3,7 & 0,2 & 13,3 & 108,8 & 3,7 & 0,2 & 13,3 & 105,7 \\
\hline Rhus typhina L. & 0,5 & 2 & 1 & 1 & 58,8 & 3 & 1 & 1 & 85,7 \\
\hline $\begin{array}{c}\text { Crataegus monogyina } \\
\text { Jacq. }\end{array}$ & 1,1 & 2 & 0 & 0 & 58,8 & 2,5 & 0,5 & 28,3 & 71,4 \\
\hline Juglans regia L. & 1,1 & 3 & 0 & 0 & 88,2 & 3,5 & 0,5 & 20,2 & 100,0 \\
\hline $\begin{array}{c}\text { Aesculus hypocastanum } \\
\text { L. } \\
\end{array}$ & 2,2 & 4 & 0 & 0 & 117,6 & 4 & 0 & 0 & 114,3 \\
\hline $\begin{array}{l}\text { Malus domestica } \\
\text { Borkh. }\end{array}$ & 0,5 & 3 & l & l & 88,2 & 3 & l & l & 85,7 \\
\hline $\begin{array}{c}\text { Cedrus atlantica } \\
\text { (Endl.)Man. Ex Carr. }\end{array}$ & 3,8 & 4 & 0 & 0 & 117,6 & 4 & 0 & 0 & 114,3 \\
\hline $\begin{array}{c}\text { Abies concolor Lindl.et } \\
\text { Gord. }\end{array}$ & 0,5 & 4 & I & I & 117,6 & 3 & I & I & 85,7 \\
\hline Picea abies Karst. & 1,1 & 3 & 0 & 0 & 88,2 & 3 & 0 & 0 & 85,7 \\
\hline $\begin{array}{c}\text { Liriodendron tulipifera } \\
\text { L. } \\
\end{array}$ & 0,5 & 5 & / & l & 147,1 & 5 & l & l & 142,9 \\
\hline $\begin{array}{c}\text { Prunus } \\
\text { cerasus L. }\end{array}$ & 11,4 & 3,9 & 0,08 & 9,3 & 114,7 & 3,8 & 0,09 & 10,6 & 108,6 \\
\hline Average & & 3,4 & 0,1 & 12,0 & 100 & 3,5 & 0,2 & 18,2 & 100 \\
\hline
\end{tabular}


Out of the total number of 26 species recorded on this area, 9 species possess allergenic characteristics of pollen. The species Betula pendula Roth., which pollen has very conspicuous allergenic characteristics, is present on this area with 13 trees. The species of the genus Tilia spp., with moderately to strongly conspicuous characteristics of pollen, also have 13 trees. There has been recorded somewhat higher number of trees with moderately conspicuous allergenic characteristics of pollen. The total number of 26 trees, arranged into three species (Acer platanoides L. - 21 trees, Acer campestre L. - 4 trees, Thuja orientalis L. - 1 tree) possess the aforementioned characteristic of pollen. The two species (Cedrus atlantica (Endl.) Man. Ex Carr. - 7 trees and Abies concolor Lindl. et Gord. - 1 tree) are characterized by weakly conspicuous allergenic characteristics of pollen, while the one species (Juglans regia L. - 2 trees) possesses very weakly conspicuous characteristics of pollen. 38 trees of the invasive species Robinia pseudoacacia L. have been recorded on this green area, and the same species is present in the nearby surroundings.

Woody species on the green areas in urban environment improve the conditions of the environment and have positive influence on the quality of city life and human health (Stavretović et al. 2010, Ninić-Todorović et al., 2015, Vujičić et al. 2016). Stavretović et al. (2010) measured the elements of growth and estimated the indicators of vitality and decorativeness of trees in Mali park in Obrenovac (part of Belgrade). The results of their research have showed that the trees of the species Platanus $x$ acerifolia (Ait.) Willd., Tilia grandifolia DC. and Fraxinus ornus had the best functional characteristics. Species Platanus $x$ acerifolia (Ait.) Willd., Populus bolleana Lauche, Ulmus effusa Willd. were singled out, as representative species of significant vitality and decorative value in Futoški park in Novi Sad (Ninić-Todorović et al. 2015)

All allergenic species are divided into three groups: trees, grass and weed. 24 species are kept track of in Serbia, because their pollen has allergenic characteristics: hazel bush, alder, yew, cypresses, elm, poplars, maple, willow, ash, birch, hornbeam, platanus, walnut tree, oak, pine, hemp, grass, linden, plantagineum, sorrel, nettle, pigweed, wormwood and ambrosia (Nestorović et al. 2011). Likewise, there are three maximums of pollen concentration in the air in Serbia: early spring - anemophilic trees and bushes, summer - grass, and summer-autumn herbaceous biannual weed. Pollen of the species Betula pendula Roth. is very strong allergen, and it could be found in big concentrations in the air - up to 5000 pollen grains $/ \mathrm{m}^{3}$ in air (Puc 2003). As it has already been stated, besides trees, grass and weed are also allergenic species. The numerous authors (Stavretović et al. 2006, Stavretović et al. 2010a; Stavretović et al., 2010b, Stavretović et al. 2011, Petrović et al. 2013) have noted a significant presence of allergenic species of grass and weed on different types of urban green areas.

\section{CONCLUSIONS}

On the study green areas of 4 kindergartens in the suburbs of Belgrade has been recorded 41 woody species with 359 trees. The largest number of trees has been recorded on the green area which belongs to the kindergarten "Suncokreti" (the total number of 227 trees), while the smallest number of trees belong to the garden of "Ježurko" kindergarten (the total of 36 trees). 
The trees in the garden of the kindergarten "Suncokreti" prevail with regards to their height (the average height is $15.7 \mathrm{~m}$ ) and the treetop width (the average value is 8.7) when compared to the trees on the other areas. As opposed to this, the lowest average values of treetop height and width belong to the trees in the garden around "Gorica". The highest average evaluations of vitality and decorativeness belong to the trees located on the green areas of the kindergartens "Ježurko" and "Nevena". A significant number of young trees, without any visible signs of illness or damage, has been noticed here, what resulted in high average evaluations of vitality and decorativeness. The trees which belong to the kindergarten "Suncokreti" have been given the lowest average evaluations of vitality and decorativeness.

Allergenic species are present in a significant number on these researched areas (133 trees (37.0\%). The largest number of allergenic trees has been recorded in the garden of the kindergarten "Suncokreti" (62 trees), while the smallest number has been noticed in the garden of the kindergarten "Nevena" (12 trees). The maximum recorded number of the species with allergenic characteristics Betula pendula Roth. and Tilia spp. has been recorded on the green area of the kindergarten "Suncokreti" (13 each). The biggest number of trees which pollen has allergenic characteristics to a certain extent belongs to the category of species with moderately conspicuous allergenic characteristics of pollen. Invasive species have been spotted only on the green area of the kindergarten "Suncokreti" (Robinia pseudoacacia L. - 38 trees). With regards to that, monitoring the state of this area is necessary in order to avoid uncontrolled spreading of the species Robinia pseudoacacia L.. Woody species on the green areas in urban environment improve the conditions of that environment and have positive influence on the quality of city life. The dynamics of growth and development of woody species, as well as their vitality and decorativeness depend on the conditions in which the species grow.

While planning and designing, it would be desirable not to predict allergenic woody species on the green areas of kindergartens. The trees that are planned for logging on these areas should be replaced with the species which do not have allergenic characteristics, or at least with the species which allergenic characteristics of pollen are very weakly conspicuous. It would be advisable also to conduct regular maintenance, especially mowing, which would reduce and put under the control allergenic herbaceous species. The species with the invasive character are not desirable either because of the possibility of instant and quick spreading and thus endangering the survival of the other species as well as disturbing the aesthetics of the mere green area. The species which possess some poisonous parts, as well as the species with thorns, are also not desirable on the green areas of kindergartens.

\section{ACKNOWLEDGEMENTS}

This paper was realized as a part of the project "Studying climate change and its influence on the environment: impacts, adaptation and mitigation"(43007) financed by the Ministry of Education and Science of the Republic of Serbia within the framework of integrated and interdisciplinary research for the period 2011-2017. 


\section{REFERENCES}

Banković, S. and Pantić, D. (2006): Dendrometrija. Beograd, Srbija, Šumarski fakultet.

Boršić, I., Milović, M., Dujmović, I., Bogdanović, S., Cigić, P., Rešetnik, I., Nikolić, T. and Mitić, B. (2008): Preliminay check-list of invasive alien plant species in Croatia. Natura Croatica. 17: $55-71$.

Bell, A. and Dyment, J. (2008): Grounds for health: the intersection of green school grounds and health promoting schools. Environmental Education Research 14: 77-90.

D’amato, G., Cecchi, L., Bonini, S., Nunes, C., Annesi Maesano, I., Behrendt, H. and Van Cauwenberge, P. (2007): Allergenic pollen and pollen allergy in Europe. Allergy 62: 976990.

Dyment, J., Bell, A. and Lucas, A. (2009): The relationship between school ground design and intensity of physical activity. Children's Geographies 7, Iss. 3.

Fjørtoft, I. (2004): Landscape as Playscape: The Effects of Natural Environments on Children's Play and Motor Development. Children, Youth and Environments 14(2): 21-44.

Gačić, A. and Stavretović, N. (2008): Značaj i uticaj zelenih površina školskih dvorišta na razvoj dece. Zbornik radova „Ekološka istina $08^{e}$, ured. Radivoje Pantić, Tehnički fakultet, Univerzitet u Boru, Bor, Srbija 305-308.

Igić, R., Boža, P., Anačkov, G. and Vukov, D. (2008): Atlas alergijskih biljaka Novog Sada [Atlas of allergic plants in Novi Sad]. Novi Sad, Srbija; Prirodno-matematički fakultet u Novom Sadu, „Simbol“.

Jankovska, I., Straupe, I., Brumelis, G., Donis, J., and Kupfere, L. (2014): Urban forests of Riga, Latvia-pressures, naturalness, attitudes and management. Baltic Forestry, 20(2), 342-351.

Lucas, A. and Dyment, J. (2010): Where do children choose to play on the school ground? The influence of green design. Education 38: 3-13.

Ninić-Todorović, J., Mladenović, E., Čukanović, J., Sentić, I., Lakić, a., Todorović, D., Todorović, I. (2015): Bioecological dendroflora characteristics of the District park in Novi sad. Agriculture and Forestry, 61 (2), 51-60.

Nestorović, M., Jovanović, M., Śovljanski, G., Bajić-Bibić, Lj., and Jokić, J. (2011): Priručnik za alergene biljke. Beograd, Srbija; Prirodnjački muzej.

Pretzsch, H., Biber, P., Uhl, E., Dahlhausen, J., Rötzer, T., Caldentey, J., Koike, T., Con, T., Chavanne, A., Seifert, T., Du Toit, B., Farnden, C. and Paulet, S. (2015): Crown size and growing space requirement of common tree species in urban centres, parks, and forests. Urban Forestry \& Urban Greening, 14(3), 466-479.

Petrović, J., Stavretović, N., Đuričić, S., Jelić, I. and Mijović, B.( 2013): Invazivne biljne vrste i trčci i mravi kao potencijal njihove biološke kontrole na primjeru spomenika prirode „Bojčinska šuma“ (Vojvodina, Srbija). Šumarski list 1-2: 61-69.

Puc, M. (2003): Characterisation of pollen allergens. Annals of Agricultural and Environmental Medicine 10: 143-149.

Stavretović, N., Janjić, V. and Paunović, E. (2006): Prisutnost biljne vrste Ambrosia artemisiifolia L. u zelenim površinama Beograda. Zbornik radova naučno-stručnog skupa o prirodnim vrednostima i zaštiti životne sredine, „Ekološka istina 2006“, Sokobanja, Srbija: 321-324.

Stavretović, N., Petrović, J. and Đurić, M. (2011): Invazivne biljne vrste u travnim površinama nekih parkova. Acta herbologica 20 (2): 121-131.

Stavretović, N., Stevanović, J., and Mijović, A. (2010a): Invazivne biljne vrste u travnim površinama stambenih naselja Beograda. Acta herbologica 19 (1): 39-47.

Stavretović, N., Vučković, M. and Stajić, B. (2010b): Classification of trees and tree species in Obrenovac "Mali Park" by the elements of growth, vitality and ornamentalness. Archiv of Biological Science 62: 1119-1024.

Vrbničanin, S., Karadžić, B. and Dajić-Stevanović, Z. (2004): Adventivne i invazivne korovske vrste na području Srbije. Acta herbologica 13 (1): 1-12.

Vujičić, M., Tomićević-Dubljević, J., Tomićević-Gavrilović, D. (2016): The socioeconomic and health effect of green infrastructure on the Vračar municipality, city of Belgrade. Agriculture and Forestry 62 (3): 165-174,, DOI 10.17707/agriculturforest.62.3.1.

Vukićević, E. (1996): Dekorativna dendrologija. Beograd, Srbija; Naučna knjiga.

Vukotić-Lazar, J., Popović, S. (2016): Organized proviion of greenery in Belgrade in order to upgrade the quality of life within the city. Agriculture and Forestry 62 (4): 253-266, DOI 10.17707/agriculturforest.62.4.26.

White, R. (2004): Interaction with nature during the middle years: Its importance in children's development and nature's future. Retrieved October $28 .$. 